Journal of Engineering Sciences, Assiut University, Vol. 38, No. 3, pp.807-818, May 2010.

\title{
OPTIMIZATION OF JIGGING PROCESS USING STATISTICAL TECHNIQUE
}

\section{Mahmoud M. Ahmed*}

Mining and Metallurgical Engineering Department, Faculty of Engineering, Assiut University, Assiut 71516, Egypt

* Corresponding author. Tel.: +2 012 3971453; Fax: +2 0882332553.

E-mail address: mamoah@aun.edu.eg (M.M. Ahmed).

(Received February 24, 2010 Accepted April 24, 2010).

The jigging studies of a synthetic binary mixture of quartz and coal were carried out. The variables studied were the particle size, bed thickness, number of strokes per minute, and water level. Experiments were carried out using 24 full factorial design. The main and interaction effects on quartz recovery were evaluated using Yates' analysis. The optimum jigging condition was found by the method of steepest ascent. A product with $81.81 \%$ quartz and $97.74 \%$ recovery in the lower layer was obtained at the following optimum conditions: particle size $3.907 \mathrm{~mm}$, bed thickness $1.87 \mathrm{~cm}$, water level $4.41 \mathrm{~cm}$, and 234.3 strokes per minute.

KEYWORDS: Harz Jig, Yates' Analysis, Factorial Analysis, Interaction Effect, $t$-Test.

\begin{tabular}{|lllll|}
\hline \multicolumn{4}{|c|}{ NOMENCLATURE } \\
$b_{j} \quad$ coefficient determination & $X_{1}$ & particle size, mm & \\
$k$ & number of factors & $X_{2}$ & bed thickness, cm & \\
$R^{2}$ & coefficient of recovery in the & $X_{3}$ & water level, cm & \\
& lower layer, \% & & & \\
$R_{\text {exp }}$ & experimental response (recovery & $X_{4}$ & number of strokes & per \\
& of quartz in the lower layer), $\%$ & & minute, rpm & \\
$R_{\text {exp }}-$ & mean experimental value & $Z_{j 0}$ & principal level & \\
$R_{\text {prd }}$ & predicted quartz & $\Delta Z_{j}$ & increment & \\
$t$ & Student's t-test & $\sigma^{2}$ & variance & \\
\hline
\end{tabular}

\section{INTRODUCTION}

Jigging is a process of ore concentration carried out in any fluid whose effectiveness depends on differences in specific gravity of granular mineral particles. It consists of separation of the particles into layers of different specific gravities followed by the removal of the separated layers [1].

Jig concentration is different from other types of gravity concentration such as heavy media separation, where the separation is done directly. Stratification of bed particles in a jig concentration is achieved gradually, and the separation into products is realized after a certain time [2]. 
Though jigs are simple in operation, the jigging process as a whole is rather complicated and strongly influenced by several interrelating factors (interacting variables or parameters). These factors are directly associated with one or more of the subsystems into which the jigging process can be divided [2]. The principal subsystems are the jig itself and the drive unit providing a pre-designed stroke pattern, as well as, feeding, feed distribution, evacuation of strata, and conveyance from jig mechanisms [2].

Many of the jigging factors are inherently controllable (manipulated variables), but some uncontrollable factors (disturbance variables) associated with the ore to be treated also play an important role in the separation process. The basic factors that affect on jig performance were reviewed by many authors [2-4]. The jig bed is divided into two zones. The concentrate zone consists of the bottom layers, where the content of heavy mineral should be greater than $95 \%$. This limit represents a certain concentrate quality [2].

One of the most effective techniques to study process behavior is the factorial designed tests with analysis of variance [5-10]. There are several advantages of statistical design of experiments over classical one variable at a time method, where one variable is varied at a time. In statistical design, experiments can be conducted in an organized manner and can be analyzed systematically to obtain much needed information. These information can be utilized for optimization purpose.

A review of jigging separation literature indicates that many authors studied the analysis of jigging for improved performance [11-13]. Other researchers carried out the mathematic modeling and simulation of particles motion into the jig [14-17]. There is a lack of statistically based studies on the effects and/or interactions of different variables on jigging process.

The main objective of the current work is to determine the main and interactions effects of jigging variables, using statistical techniques, on complete stratification process of mineral particles in jig and find out optimum condition. This is done through a $2^{4}$ factorial design with mid-point replicates.

The different aims of optimization strategy used in this study are to design experimental tests (using factorial design) of separation in Harz jig, to perform an analysis of the experimental results by ANOVA to determine the significant factors influencing the jigging process, and to find out the optimum conditions of jigging process.

\section{EXPERIMENTAL}

\subsection{Materials}

The tests were run on a batch basis using a synthetic binary mixture of heavy and light minerals. The mixture consists of quartz (sp. gr. $=2.65 \mathrm{~g} / \mathrm{cm}^{3}$ ) and coal (sp. gr. $=1.30$ $\mathrm{g} / \mathrm{cm}^{3}$ ) with a percent of $1: 1$ by weight. The concentration criterion of the mixture is about 5.5 which means that high promise separation efficiency will be expected for the current process. Vijayendra [1] stated that if the concentration criterion is a negative or positive number greater than 2.5 , separation in water is easy at all sizes down to the finest sands. Two size fractions of $(-8+6.3) \mathrm{mm}$ and $(-1.6+1.25) \mathrm{mm}$ of two minerals were prepared to be used in the experiments. Two different weights of the mixture were used, i.e. $200 \mathrm{gm}$ with the high level and $100 \mathrm{gm}$ with the low level. 


\subsection{Methods}

A laboratory fixed-sieve jig was used. It is a single-hutch Harz-type machine. It consists of one rectangular hopper shaped compartment called external cell with a size of $10 \times 8 \times 12 \mathrm{~cm}$. The internal cell consists of a rectangular box with a size of $6 \times 6 \times 8$ $\mathrm{cm}$, ended with a wire screen of $1 \mathrm{~mm}$ size.

In each experiment, the required weights of two minerals are well mixed and put into the internal jig cell. The cell is then connected with the drive unit and put into the external cell, which is filled with water.

The bed thickness, number of strokes per minute, and water level are set accordingly to the required values for each particular experiment. The stroke length is fixed to about $12 \mathrm{~mm}$. The jigging time is set at 45 seconds. These two variables are maintained constant during all experiments.

In each experiment and after the separation is attained, the machine is stopped. The internal cell is separated from the drive unit and taken out of the water. The level of cutting (or removal) of the jigging products is taken as the height of heavy mineral when complete separation is attained.

Both the upper layer and the lower layer are collected separately, dried and analyzed for quartz percent. The content of the heavy mineral (quartz) in the jigging products is determined by the heavy-liquid separation process. The raw data of experimental results are tabulated in Table 1 . The grade and recovery of quartz in the lower layer are calculated using the following formulas:

$\%$ Grade $=100 \times \frac{\text { Weightof quartzin thelower layer }}{\text { Totalweight of lower layer }}$

$\%$ Recovery $=100 \times \frac{\text { Totalweight of lower layer } \mathrm{x} \% \text { of quat } \mathrm{zin} \text { lower layer }}{\text { Totalweight of feed } \mathrm{x} \% \text { of quartzin feed }}$

Table 1: Raw data of experimental results

\begin{tabular}{|c|c|c|c|c|c|}
\hline \multicolumn{3}{|c|}{ Light layer } & \multicolumn{3}{c|}{ Heavy layer } \\
\hline wt, gm & Coal\% & Quartz\% & wt, gm & Coal\% & Quartz\% \\
\hline 44.00 & 91.09 & 8.91 & 51.50 & 11.31 & 88.69 \\
35.50 & 97.18 & 2.82 & 64.50 & 23.26 & 76.74 \\
121.00 & 61.88 & 38.12 & 71.00 & 28.41 & 71.59 \\
120.00 & 53.33 & 46.67 & 73.50 & 40.82 & 59.18 \\
41.50 & 89.24 & 10.76 & 53.00 & 15.21 & 84.79 \\
35.50 & 88.73 & 11.27 & 61.50 & 25.20 & 74.80 \\
91.50 & 87.49 & 12.51 & 100.50 & 12.88 & 87.12 \\
111.50 & 61.88 & 38.12 & 82.50 & 31.52 & 68.48 \\
47.00 & 87.48 & 12.52 & 48.00 & 9.40 & 90.60 \\
37.50 & 97.33 & 2.67 & 61.50 & 17.89 & 82.11 \\
87.00 & 97.37 & 2.63 & 104.50 & 6.71 & 93.29 \\
93.00 & 90.86 & 9.14 & 106.50 & 12.68 & 87.32 \\
40.50 & 90.82 & 9.18 & 54.50 & 15.92 & 84.08 \\
40.50 & 95.06 & 4.94 & 58.00 & 18.10 & 81.90 \\
92.50 & 93.88 & 6.12 & 100.50 & 6.56 & 93.44 \\
93.50 & 93.05 & 6.95 & 105.00 & 10.95 & 89.05 \\
\hline
\end{tabular}




\subsection{Variables}

The variables considered in this study are: particle size $\left(\mathrm{X}_{1}\right)$, bed thickness $\left(\mathrm{X}_{2}\right)$, water level $\left(\mathrm{X}_{3}\right)$, and number of strokes per minute $\left(\mathrm{X}_{4}\right)$. The levels of variables are given in Table 2.

Table 2: The variables and levels of $2^{4}$ factorial design for jigging process

\begin{tabular}{lccccc}
\hline Variables & Code & $\begin{array}{c}\text { Low level } \\
(-1)\end{array}$ & $\begin{array}{c}\text { Base level } \\
(0)\end{array}$ & $\begin{array}{c}\text { High level } \\
(+)\end{array}$ & $\begin{array}{c}\text { Step } \\
\text { size }\end{array}$ \\
\hline Particle size, $\mathrm{mm}$ & $\mathrm{X}_{1}$ & 1.425 & 4.288 & 7.150 & 2.863 \\
Bed thickness, cm & $\mathrm{X}_{2}$ & 1.570 & 2.415 & 03.26 & 0.845 \\
Water level, cm & $\mathrm{X}_{3}$ & 03.10 & 4.175 & 05.25 & 1.075 \\
Number of strokes, rpm & $\mathrm{X}_{4}$ & 151.1 & 200.5 & 249.9 & 49.40 \\
\hline
\end{tabular}

\subsection{Coding and General Form of Response Equation with Main and Interaction Effects}

The statistical design of experiments is useful in that the simultaneous assessment of several factors can be made by determining the main and interaction effects. Each value of jigging variables was converted into the following three coding levels: $-1,+1$ and 0 for low, high and center point, respectively. The center point is the arithmetic mean of the high and low levels. Quartz recovery in the lower layer has been treated as "response".

The matrix for four variables varied at two levels $(+,-)$ and the corresponding recovery and grade of quartz in the lower layer are shown in Table 3 . According to the basic principle of the design of experiments, four experiments were carried out at the base level (Table 2) to estimate error and standard deviation.

Table 3: $2^{4}$ full factorial design matrix for jigging process

\begin{tabular}{ccccccc}
\hline Observation & \multicolumn{9}{c}{ Coded factors } & \multicolumn{2}{c}{ Response } \\
\hline & $\mathrm{X}_{1}$ & $\mathrm{X}_{2}$ & $\mathrm{X}_{3}$ & $\mathrm{X}_{4}$ & Recovery, \% & Grade, \% \\
\hline 1 & - & - & - & - & 92.09 & 88.69 \\
2 & + & - & - & - & 98.02 & 76.74 \\
3 & - & + & - & - & 52.43 & 71.59 \\
4 & + & + & - & - & 43.72 & 59.18 \\
5 & - & - & + & - & 90.96 & 84.79 \\
6 & + & - & + & - & 92.00 & 74.80 \\
7 & - & + & + & - & 88.44 & 87.12 \\
8 & + & + & + & - & 57.07 & 68.48 \\
9 & - & - & - & + & 88.08 & 90.60 \\
10 & + & - & - & + & 98.06 & 82.11 \\
11 & - & + & - & + & 97.70 & 93.29 \\
12 & + & + & - & + & 91.63 & 87.32 \\
13 & - & - & + & + & 92.49 & 84.08 \\
14 & + & - & + & + & 95.96 & 81.90 \\
15 & - & + & + & + & 94.31 & 93.44 \\
16 & + & + & + & + & 93.50 & 89.05 \\
\hline
\end{tabular}


Minitab statistical software was used for the analysis of experimental data from the randomized tests with designed conditions, which yielded the main and interaction effects that are specific to the jigging system under investigation. The main effect of a factor is given as the change in a response produced by the change between the upper and lower level of that factor. A general expression representing the main and interaction effects for the $2^{4}$ factorial design is given below [18]:

$$
\begin{aligned}
& \text { Response }=\beta 0+\beta \mathrm{a} X_{1}+\beta b X_{2}+\beta a b X_{1} \cdot X_{2}+\beta c X_{3}+\beta a c X_{1} \cdot X_{3}+\beta b c X_{2} \cdot X_{3}+ \\
& \beta a b c X_{1} \cdot X_{2} \cdot X_{3}+\beta d X_{4}+\beta a d X_{1} \cdot X_{4}+\beta b d X_{2} \cdot X_{4}+\beta a b d X_{1} \cdot X_{2} \cdot X_{4}+ \\
& \beta c d X_{3} \cdot X_{4}+\beta a c d X_{1} \cdot X_{3} \cdot X_{4}+\beta b c d X_{2} \cdot X_{3} \cdot X_{4}+\beta a b c d X_{1} \cdot X_{2} \cdot X_{3} \cdot X_{4}
\end{aligned}
$$

$\beta 0, \beta a, \beta b, \beta a b, \beta c, \beta a c, \beta b c, \beta a b c, \beta d, \beta a d, \beta b d, \beta a b d, \beta c d, \beta a c d, \beta b c d$ and $\beta a b c d$ represent the coefficients. The main and interaction effects can be calculated by using matrices and details of such calculations can be found in the general source referred to above [18].

\section{RESULTS AND DISCUSSION}

The experimental data were analyzed statistically. The effect of the variables were quantified and interpreted.

\subsection{Statistical Analysis}

The statistical design of experiments is used when the effect of several factors are to be studied in order to determine the main and interaction effects. The effect of a variable is the change in response produced by varying the level of the factor. When the effect of a factor depends on the level of another factor, the two factors are said to interact.

In the present work, four variables were taken into consideration to evaluate their main and interaction effects on the recovery of quartz in the lower layer to study the separation of quartz from coal. In other words, the main goal has been to establish the best set of variables that could be used in jig to obtain maximum recovery in the lower layer with an acceptable grade.

A $2^{4}$ full factorial un-replicated jigging experiments were carried out in order to evaluate the main and interaction effects of variables on jigging process. Yates' notation has been used in this work to name each treatment [19]. For example, treatment "ab" is the experimental run in which the variables $X_{1}$ and $X_{2}$ are set at their high level whereas the variables $X_{3}$ and $X_{4}$ are at their low level. Treatment "acd" is the experimental run in which the variables $X_{1}, X_{3}$ and $X_{4}$ are set at their high level whereas the variable $X_{2}$ is at its low level, and so on.

To study the main and interaction effects of the variables on the recovery of quartz, Yates' analysis and analysis of variance have been carried out [19]. The total variance (total mean square) of a factorial experiment can be divided into several sources using Yates' analysis. In case of un-replicated experiments, all the variance is subdivided between the effects.

A $2^{4}$ experiment has $\left(2^{4}-1\right)$ degree of freedom, and Yates' analysis divides the total variation in the results into the 15 effects. It follows that each effect has one degree of freedom; hence, for any effect, the mean square equals the sum of squares. 
In Yates' analysis, the standard addition and subtraction in pairs is carried out by $n$ times for $\mathrm{n}$ factors. The Yates' analysis and analysis of variance for quartz recovery are given in Table 4. The test of statistical significance of each effect necessitates estimation of experimental error.

Table 4: Results of statistical analysis and test of significance of main and interaction coefficients

\begin{tabular}{ccccccccc}
\hline \multirow{2}{*}{ Code } & $\mathrm{R}_{\text {exp }}$, & \multicolumn{9}{c}{ Yates' analysis } & \multirow{2}{*}{ Effects } & \multirow{2}{*}{$\mathrm{t}_{\text {cal. }}$} & \multirow{2}{*}{ Sign. } \\
\cline { 3 - 7 } & $\%$ & 1 & 2 & 3 & 4 & & \\
\hline Average & 92.09 & 190.11 & 286.26 & 614.72 & 1366.46 & 85.404 & - & - \\
$\mathrm{X}_{1}$ & 98.02 & 96.15 & 328.47 & 751.73 & -26.55 & -1.659 & -3.66 & $\mathrm{NS}$ \\
$\mathrm{X}_{2}$ & 52.43 & 182.96 & 375.47 & -33.11 & -128.87 & -8.054 & -17.75 & 99.9 \\
$\mathrm{X}_{1} \mathrm{X}_{2}$ & 43.72 & 145.51 & 376.27 & 6.55 & -67.38 & -4.211 & -9.28 & 99.5 \\
$\mathrm{X}_{3}$ & 90.96 & 186.14 & -2.78 & -131.42 & 43.01 & 2.688 & 5.92 & 99 \\
$\mathrm{X}_{1} \mathrm{X}_{3}$ & 92.00 & 189.33 & -30.32 & 2.55 & -28.79 & -1.799 & -3.97 & $\mathrm{NS}$ \\
$\mathrm{X}_{2} \mathrm{X}_{3}$ & 88.44 & 188.45 & 3.90 & -47.04 & 52.68 & 3.293 & 7.26 & 99.5 \\
$\mathrm{X}_{1} \mathrm{X}_{2} \mathrm{X}_{3}$ & 57.07 & 187.81 & 2.65 & -20.33 & -5.99 & -0.374 & -0.83 & $\mathrm{NS}$ \\
$\mathrm{X}_{4}$ & 88.08 & 5.93 & -93.97 & 42.21 & 137.01 & 8.563 & 18.87 & 99.9 \\
$\mathrm{X}_{1} \mathrm{X}_{4}$ & 98.06 & -8.71 & -37.45 & 0.80 & 39.66 & 2.479 & 5.46 & 99 \\
$\mathrm{X}_{2} \mathrm{X}_{4}$ & 97.70 & 1.04 & 3.19 & -27.54 & 133.97 & 8.373 & 18.45 & 99.9 \\
$\mathrm{X}_{1} \mathrm{X}_{2} \mathrm{X}_{4}$ & 91.63 & -31.37 & -0.64 & -1.25 & 26.71 & 1.669 & 3.68 & $\mathrm{NS}$ \\
$\mathrm{X}_{3} \mathrm{X}_{4}$ & 92.49 & 9.98 & -14.63 & 56.52 & -41.41 & -2.588 & -5.70 & 99 \\
$\mathrm{X}_{1} \mathrm{X}_{3} \mathrm{X}_{4}$ & 95.96 & -6.08 & -32.41 & -3.83 & 26.30 & 1.644 & 3.62 & $\mathrm{NS}$ \\
$\mathrm{X}_{2} \mathrm{X}_{3} \mathrm{X}_{4}$ & 94.31 & 3.47 & -16.06 & -17.77 & -60.35 & -3.772 & -8.31 & 99.5 \\
$\mathrm{X}_{1} \mathrm{X}_{2} \mathrm{X}_{3} \mathrm{X}_{4}$ & 93.50 & -0.81 & -4.28 & 11.78 & 29.55 & 1.847 & 4.07 & $\mathrm{NS}$ \\
\hline $\mathrm{NS}=$ & non-significant & & & & & &
\end{tabular}

A suitable confidence interval of $99 \%$ is chosen for determination of significance of main and interaction effects. In the current analysis with $\mathrm{k}=4$ factors, 4 center points have been used to estimate the experimental error and the variance, $\sigma^{2}$. The variance of main and interaction effects is given by [20-21]:

$$
\begin{gathered}
\text { Variance }(\text { Effects })=\frac{\sigma^{2}}{2^{\mathrm{k}}} \\
\mathrm{t}_{\text {cal. }}=\left[\text { Calculat el mainorinteractia effect }\langle\sqrt{(\text { Variance(Effects })}] \geq \mathrm{t}_{0.01,3}\right.
\end{gathered}
$$

The value of $t_{0.01,3}$ is 4.54 , which can be obtained from the Student's $t$ distribution table and if the estimated main and interaction effects are significant at 99\% confidence level, then they will satisfy the above criteria [21]. In other words, an effect is considered to be significance if its significance level is greater than $99 \%$. The details are given in Table 4.

On eliminating the coefficients which are not significant, the statistical model can be built up for prediction of quartz recovery using Yates' analysis data (Table 4). This model can be used to perform analysis of the residues to check the assumption on the experimental error distribution of the factorial design [22]. The model formed for quartz recovery, using the effects of variables significant at $99 \%$ confidence level or more, is given below [10,21]: 
$\mathrm{R}_{\mathrm{prd}}=85.404-8.054 \mathrm{X}_{2}-4.211 \mathrm{X}_{1} \cdot \mathrm{X}_{2}+2.688 \mathrm{X}_{3}+3.293 \mathrm{X}_{2} \cdot \mathrm{X}_{3}+8.563 \mathrm{X}_{4}$

$+2.479 \mathrm{X}_{1} \cdot \mathrm{X}_{4}+8.373 \mathrm{X}_{2} \cdot \mathrm{X}_{4}-2.588 \mathrm{X}_{3} \cdot \mathrm{X}_{4}-3.772 \mathrm{X}_{2} \cdot \mathrm{X}_{3} \cdot \mathrm{X}_{4}$

$\mathrm{R}^{2}=0.94748, \mathrm{X}_{1}, \mathrm{X}_{2}, \mathrm{X}_{3}, \mathrm{X}_{4}$ are expressed in coded form -1 or +1 .

The coefficient of determination, $\mathrm{R}^{2}$, is used to check the model ability to predict the response (recovery) accurately. It is determined from the following equation:

$$
\mathrm{R}^{2}=1-\left[\sum\left\{\left(\mathrm{R}_{\text {exp }}-\mathrm{R}_{\mathrm{prd}}\right)^{2}\right\} / \sum\left\{\left(\mathrm{R}_{\exp }-\overline{\mathrm{R}}_{\exp }\right)^{2}\right\}\right]
$$

If $\mathrm{R}^{2}$ is 1 , then the prediction is nearly perfect. However, if $\mathrm{R}^{2}$ becomes zero, the model has little value. The empirical model was found to accurately estimate the response variable as indicated by $\mathrm{R}^{2}$ value $(0.95)$. The residual analysis for recovery is given in Fig. 1.

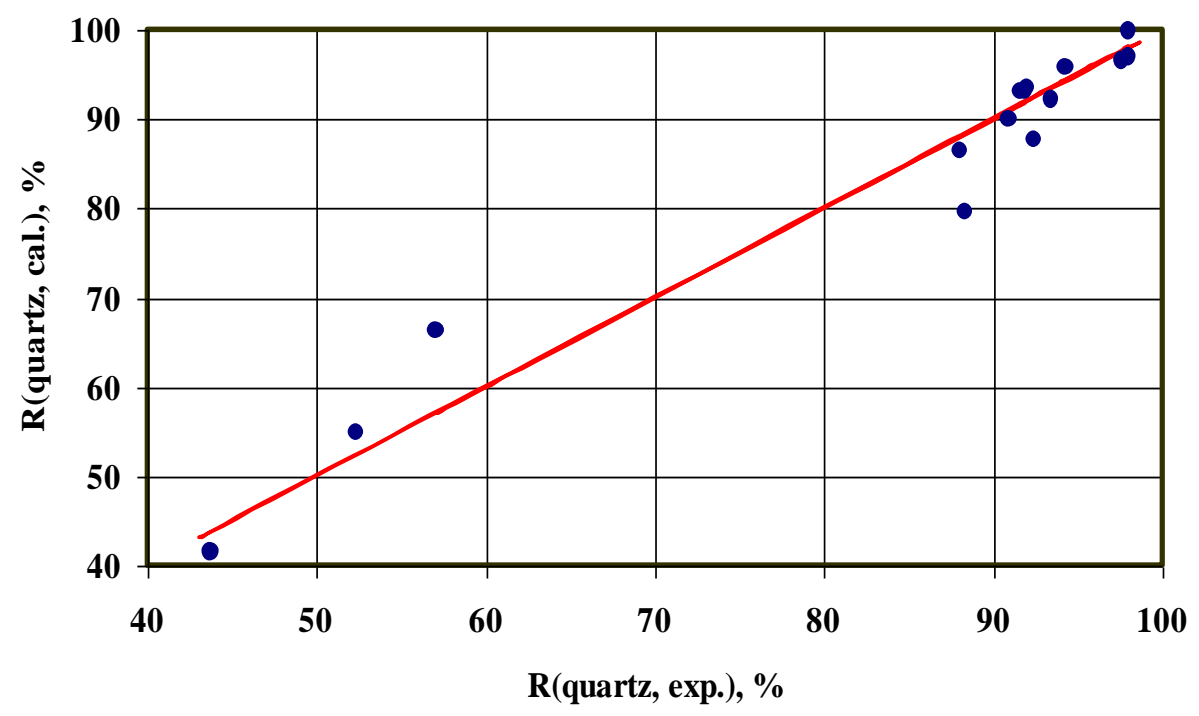

Fig. 1: Residuals analysis of quartz recovery

The effects of variables on quartz recovery are shown in Fig. 2. The main effects of all the variables on the recovery are significant at $99 \%$ confidence level except of the particle size. The order of influence is $X_{4}>X_{2}>X_{3}>X_{1}$. The most important effect is the number of strokes $\left(\mathrm{X}_{4}\right)$. It is highly significant and positive. The effect of bed thickness $\left(\mathrm{X}_{2}\right)$ is also highly significant, but negative. Of course this variable will influence contrary the mass productivity. The variable water level $\left(\mathrm{X}_{3}\right)$ has positive effect. The interpretation of variables effects on recovery in the lower layer are explained in the following sections. 


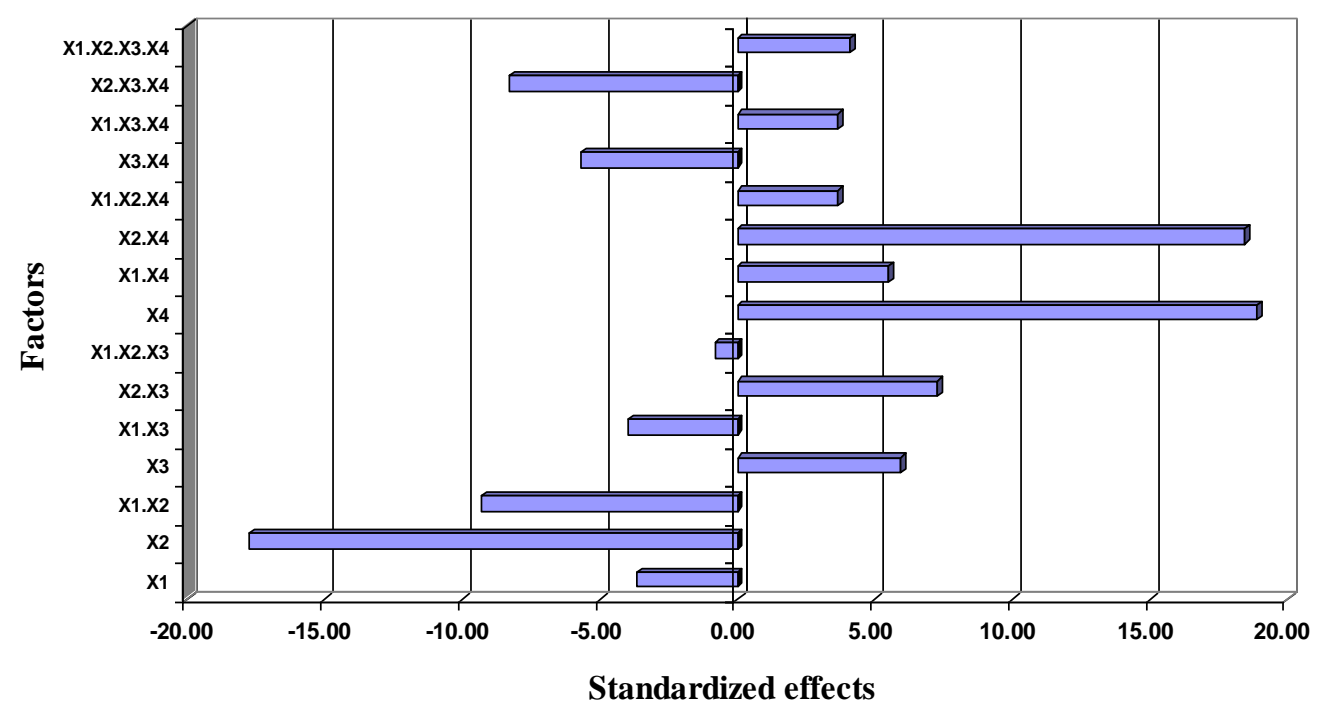

Fig. 2: Pareto chart of the standardized effects for quartz recovery, $\alpha=0.01$

A heavier and coarser feed requires a stronger cycle than a finer one [23]. The coarser the ore, the deeper the whole bed and hence greater the output is. But when the bed is too deep, the separation by gravity is hindered. When the jig contains fine particles, there are smaller voids between these smaller particles. This will improve hindered settlement, i.e. shortening the time of stratification [1]. The motion should be stronger with coarse than with fine ore. Although relatively short fall strokes are used to separate fine materials, more control and better stratification can be achieved by using longer, slower strokes, especially with the coarser particle sizes. It is therefore good practice to screen the feed to jigs into different size ranges and treat these separately [4].

The stratification process is rapid when the thickness of the jig bed is thin. This may probably due to excessive mobility of the bed. Thus the mineral particles of the bottom layers have the opportunity to rise and penetrate the top layers [2].

The higher the water level, the better separation results are. This could be attributed to a reduction in intensity and duration of suction at higher water levels as well as to greater mobility of the settling heavy mineral grains [2]. At the point of transition between the pulsion and suction stroke, the bed will be completely compacted. In a closely sized ore the heavy grains can penetrate with difficulty through the bed and may be lost to the tailings. Severe compaction of the bed can be reduced by the addition of hutch water, a constant volume of water, which creates a constant upward flow through the bed. The coarser ore then penetrates the bed more easily and the horizontal transport of the feed over the jig is also improved [4].

There are two opposite forces which determine the final rate of separation at changing the number of strokes. The first one favors the stratification and the second delays its completion. A deeper study into the mechanism of jigging using hydrodynamics as well as some concepts of theory of stochastic processes reveals that jigging is a combination of two separate, contracting processes. The first one favors 
the separation while the second remixes stratified particles at the same time [2]. Optimum frequency and stroke depend on the feed rate, the specific gravity of the feed, its granulometry, bed thickness, the type of jigging cycle employed and the intensity of suction (the supply rate of back water) [23].

From Eq. (6), it can be also revealed that although the particle size $\left(X_{1}\right)$ has no significant effect on the recovery, its interaction with other variables is significant at 99\% level and has clear effect on the recovery. It interacts with the variable bed thickness $\left(\mathrm{X}_{1} \cdot \mathrm{X}_{2}\right)$ and decreases the recovery significantly. The variable $\left(\mathrm{X}_{1}\right)$ interacts also with the number of strokes $\left(X_{1} \cdot X_{4}\right)$ and increases the recovery. The variable water level $\left(\mathrm{X}_{3}\right)$, which has positive effect, interacts with the negative effect variable $\left(\mathrm{X}_{2}\right)$ and increases the recovery. This variable $\left(\mathrm{X}_{3}\right)$ interacts with the variable $\left(\mathrm{X}_{4}\right)$ and decreases recovery with negative interaction. The most important effect of all interactions is $\left(\mathrm{X}_{2} \cdot \mathrm{X}_{4}\right)$. This interaction is highly significant and increases the recovery positively. The interaction $\left(\mathrm{X}_{2} \cdot \mathrm{X}_{3} \cdot \mathrm{X}_{4}\right)$ is significant at $99 \%$ confidence level and has negative affect, i.e. it decreases the recovery.

\subsection{Optimization}

One of the techniques of optimization is the method of steepest ascent, in which the base point is assumed and the next set of values is selected, which is proportional to product of the coefficient and step size. The selected values are incremented successively and objective function is evaluated each time till the optimum point is reached.

In this work, our objective was to maximize recovery of quartz in the lower layer of jig product. Eq. (6) was used to determine the increment size for recovery. The variables having positive effects were increased and the variables having negative effects were decreased according to the increment size (Table 5) and evaluated by carrying out successive experiments. The results obtained with their variables are given in Table 6.

Table 5: Results of evaluation of optimized variables for optimum recovery

\begin{tabular}{lcccc}
\hline Variable & $\begin{array}{c}\text { particle size } \\
\left(\mathrm{X}_{1}\right), \mathrm{mm}\end{array}$ & $\begin{array}{c}\text { bed thickness } \\
\left(\mathrm{X}_{2}\right), \mathrm{cm}\end{array}$ & $\begin{array}{c}\text { water level } \\
\left(\mathrm{X}_{3}\right), \mathrm{cm}\end{array}$ & $\begin{array}{c}\text { number of } \\
\text { strokes }\left(\mathrm{X}_{4}\right), \\
\mathrm{rpm}\end{array}$ \\
\hline Principal level, $\mathrm{Z}_{\mathrm{j} 0}$ & 4.288 & 2.415 & 4.175 & 200.500 \\
Increment, $\Delta \mathrm{Z}_{\mathrm{j}}$ & 2.863 & 0.845 & 1.075 & 049.400 \\
Coefficient, $\mathrm{b}_{\mathrm{j}}$ & -1.659 & -8.054 & 2.688 & 008.563 \\
$\Delta \mathrm{Z}_{\mathrm{j}}{ }^{\mathrm{b}} \mathrm{b}_{\mathrm{j}}$ & -4.750 & -6.806 & 2.889 & 423.017 \\
Normal steps & -0.095 & -0.136 & 0.058 & 008.460 \\
\hline
\end{tabular}

Eq. (6) indicates that the effects of number of strokes per minute $\left(\mathrm{X}_{4}\right)$ and water level $\left(\mathrm{X}_{3}\right)$ are positive, whereas that of bed thickness $\left(\mathrm{X}_{2}\right)$ and particle size $\left(\mathrm{X}_{1}\right)$ are negative. The results of the experiments are given in Table 6 . The optimum condition was found to be at particle size $3.907 \mathrm{~mm}$, bed thickness $1.87 \mathrm{~cm}$, water level $4.41 \mathrm{~cm}$, and 234.3 strokes per minute. At these conditions, a lower layer product with $81.81 \%$ quartz at $97.74 \%$ quartz recovery was obtained. 
Table 6: Optimization of quartz recovery in the lower layer product

\begin{tabular}{cccccc}
\hline & \multicolumn{2}{c}{ Variables } & \multicolumn{2}{c}{ Response } \\
\hline $\begin{array}{c}\text { particle size } \\
\left(\mathrm{X}_{1}\right), \mathrm{mm}\end{array}$ & $\begin{array}{c}\text { bed thickness } \\
\left(\mathrm{X}_{2}\right), \mathrm{cm}\end{array}$ & $\begin{array}{c}\text { water level } \\
\left(\mathrm{X}_{3}\right), \mathrm{cm}\end{array}$ & $\begin{array}{c}\text { number of strokes } \\
\left(\mathrm{X}_{4}\right), \mathrm{rpm}\end{array}$ & $\begin{array}{c}\text { Recovery, } \\
\%\end{array}$ & $\begin{array}{c}\text { Grade, } \\
\%\end{array}$ \\
\hline 4.192 & 2.279 & 4.233 & 208.960 & 91.54 & 85.18 \\
4.097 & 2.143 & 4.291 & 217.421 & 95.94 & 82.57 \\
4.002 & 2.007 & 4.348 & 225.881 & 97.38 & 82.24 \\
3.907 & 1.871 & 4.406 & 234.341 & 97.74 & 81.81 \\
\hline
\end{tabular}

\section{CONCLUSIONS}

A confidence interval of 99\% was chosen for determination of significance of main and interaction effects. Four experiments at the center points were carried out to estimate the experimental error and variance. The main effects of all the variables on the recovery were significant at $99 \%$ confidence level except of the particle size. The order of influence was: number of strokes $>$ bed thickness $>$ water level $>$ particle size. The most important effect was the number of strokes which had a positive response. The effect of bed thickness was also highly significant, but negative. The water level had positive effect. The empirical model was found to accurately predict the quartz recovery where the coefficient of determination was about 0.95 . An optimum product with $81.81 \%$ grade and $97.74 \%$ recovery of quartz in the lower layer was obtained at particle size $3.907 \mathrm{~mm}$, bed thickness $1.87 \mathrm{~cm}$, water level $4.41 \mathrm{~cm}$, and 234.3 strokes per minute.

\section{REFERENCES}

[1] H.G. Vijayendra: 'Gravity concentration', A Handbook on Mineral Dressing, $2^{\text {nd }}$ edn, 149-183, 2001, Vikas Publishing House PVT LTD, New Delhi.

[2] J.A. Herbest: 'Contribution to the modeling of the jigging process', Control 84 Mineral/Metallurgical Processing, Ch. 12, 97-105, 1984, Society of Mining Engineers, AIME, SME/TMS, New York.

[3] M.M. Tarshan and A.A. Ahmed: 'Analysis of jig performance', Bulletin of the Faculty of Engineering, Assiut University, 16, Part 2, July 1988, 177-190.

[4] B.A. Wills: 'Gravity concentration', (ed. T. Napier-Munn), Mineral Processing Technology, $7^{\text {th }}$ edn, 225-245, 2006, Elsevier, Amsterdam.

[5] P.K. Naik: 'Quantification of induced roll magnetic separation of mineral sands', Scandinavian Journal of Metallurgy, 31 (6), 367-373, 2002.

[6] P.K. Naik, L.B. Sukla and S.C. Das: 'Aqueous $\mathrm{SO}_{2}$ leaching studies on nishikhal manganese ore through factorial experiment', Hydrometallurgy, 54, 217-228, 2000.

[7] R.N. Sahoo, P.K. Naik and S.C. Das: 'Extraction of manganese from low grade manganese ore using oxalic acid as reductant', Hydrometallurgy, 62 (3), 157-163, 2001.

[8] P.K. Naik, L.B. Sukla and S.C. Das: 'Application of statistical design in the leaching study of low grade manganese ore using aqueous sulfur dioxide', Separation Science and Technology, 37 (6), 1375-1389, 2002. 
[9] P.K. Naik, L.B. Sukla and S.C. Das: 'Extraction of manganese from low grade nishikhal ore using pyritiferous lignite in acidic medium', Minerals and Metallurgical Processing, 19 (2), 110-112, 2002.

[10] P.K. Naik, P.S.R. Reddy and V.N. Misra: 'Optimization of coal flotation using statistical technique', Fuel Process. Technol., 85, 2004, 1473-1485.

[11] K. Hori, M. Tsunekawa, N. Hiroyoshi and M. Ito: 'Optimum water pulsation of jig separation for crushed plastic particles’, Int. J. Miner. Process, 92, 2009, 103108.

[12] A.K. Mukherjee and B.K. Mishra: 'An integral assessment of the role of critical process parameters on jigging', Int. J. Miner. Process, 81, 2006, 187-200.

[13] A.K. Mukherjee, V.K. Dwivedi and B.K. Mishra: 'Analysis of a laboratory jigging system for improved performance', Minerals Engineering, 18, 2005, 10371044.

[14] K. Ya-li, Z. Jun, Z. Hai-yang and G. Jun: 'Mathematic simulation of $+13 \mathrm{~mm}$ particles motion in jig', Procedia Earth and Planetary Science, 1, 2009, 819-829.

[15] Y. Xia, F.F. Peng and E. Wolfe: 'CFD simulation of fine coal segregation and stratification in jigs', Int. J. Miner. Process, 82, 2007, 164-176.

[16] B.K. Mishra and S.P. Mehrotra: 'A jig model based on the discrete element method and its experimental validation', Int. J. Miner. Process, 63, 2001, 177-189.

[17] B.K. Mishra and S.P. Mehrotra: 'Modeling of particle stratification in jigs by the discrete element method', Minerals Engineering, 11 (6), 1998, 511-522.

[18] D.C. Montgomery and G.C. Runger: 'Applied Statistics and Probability for Engineers', $3^{\text {rd }}$ edn, 2002.

[19] L. Davies: 'Efficiency in research, development, and production', The Statistical Design and Analysis of Chemical Experiments, p. 180, 1993, The Royal society of Chemistry, Cambridge, UK.

[20] P. K. Naik, P. S. R. Reddy, V. N. Misra: 'Interpretation of interaction effects and optimization of reagent dosages for fine coal flotation', Int. J. Miner. Process., 75, 2005, 83-90.

[21] S. Kelebek, U. Demir, O. Sahbaz, A. Ucar, M. Cinar, C. Karaguzel and B. Oteyaka: 'The effects of dodecylamine, kerosene and $\mathrm{pH}$ on batch flotation of Turkey's Tuncbilek coal', Int. J. Miner. Process., 88, 2008, 65-71.

[22] D.C. Montgomery: 'Design and Analysis of Experiments', $3^{\text {rd }}$ edn, 1991, Wiley, Singapore.

[23] G. Tarjan: 'Concentration by gravity', Mineral Processing, Vol. II, 7-112, 1986, Akademiai Kiado, Budapest. 


\section{أمثلية عملية الخضخضة بإستخدام التحليل الإحصائي}

في هذا البحث تم عمل دراسة بإستخدام التحليل الإحصائي على جهاز الخضخضة حيث تم دراسة كلاً من حجم الحيبات - سمك الطبقة - عدد المشاوير في الدقيقة - منسوب الماء.

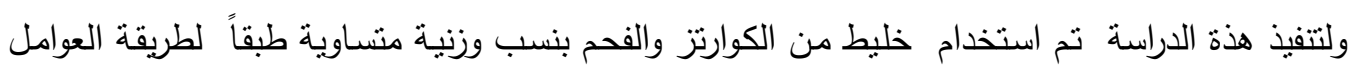
حيث نم تحديد القيم المثلي لمتغيرات التشغيل. تم الحصول على منتج بنسبة 81.81\% كوارتز و بإسترجاع قدره 97.74\% في الطبقة السفلى مـع العلم بأن هذا المنتج نم الحصول عليه عند الظروف القصوى للتتغيل وهى كالآتى: حجم الحبيبات 3.91 مم، سمك الطبقة 1.87 سم، منسوب الماء 4.41 سم, و أخيرا 234.3 مشوار في الدقيقة. تم إختيار فترة ثقة قدرها 99\% لتحديد دقة المتغيرات الرئيسية والمتداخلة. و ولقد وجد أن كل المتغيرات الرئيسية لها تأثثر معنوي واضح على إسترجاع الكوارتز فى الطبقة السفلى عدا حجم الحبيبات. أمسا

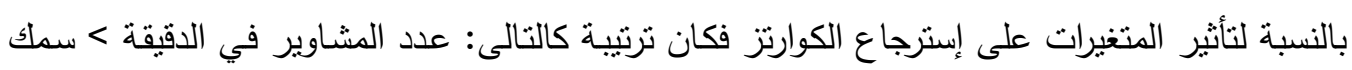
الطبقة > مستوى الماء > حجم الحبيية. مع ملاحظة أن عدد المشاوير في الدقيقة كان هو الأكثر تأثيرا وكان تأثثره إيجابيا أما بالنسبة لسمك الطبقة فكان أيضا ذو نأثير كبير ولكن بصوره سلبيه.

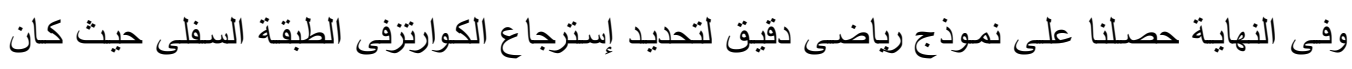
معامل الإرتباط للنتائج مقداره 95. 